\title{
The Quotable Darwin
}





\section{The Quotable Darwin}

Collected and edited by

Janet Browne

PRINCETON UNIVERSITY PRESS

Princeton and Oxford 
Copyright ( $(2018$ by Janet Browne

Requests for permission to reproduce material from this work should be sent to Permissions, Princeton University Press

Published by Princeton University Press, 41 William Street, Princeton, New Jersey 08540 In the United Kingdom: Princeton University Press, 6 Oxford Street, Woodstock, Oxfordshire OX20 1TR

press.princeton.edu

Jacket image: Oil portrait of Charles Darwin, 1881, by John Collier. Color reproduction courtesy of the Linnean Society.

All Rights Reserved

ISBN 978-0-691-16935-4

Library of Congress Cataloging in Publication

Control Number: 2017003239

British Library Cataloging-in-Publication Data is available

This book has been composed in Wilke and Palatino

Printed on acid-free paper. $\infty$

Printed in the United States of America

13579108642 